\title{
Settlement of Land Rights Disputes (Legal Study of Supreme Court Ruling No. 78 PK/TUN/2011)
}

\author{
Rahadian Dikara ${ }^{1}$ Hirsanuddin $^{2} \quad$ Sahnan $^{2}$ \\ 1.Graduate Program Student in Notary, Faculty of Law, Mataram University, Indonesia \\ 2.Lecturer of Faculty of Law, Mataram University, Indonesia
}

\begin{abstract}
This research discusses the settlement of land rights disputes. The problem is how the basic legal consideration of land rights above the Managemen Rights (hereinafter referred to HPL) certificate in the Special Economic Area Mandalika Central Lombok District and why the dispute on land rights that has a permanent legal force or inmate in the Special Economic Area Mandalika Central Lombok (Supreme Court decision No. 78 PK/TUN/2011) can not be executed. This research aims to know and analyze the basic legal considerations and dispute on land rights that has a permanent legal force or inmate in the Special Economic Area Mandalika Central Lombok (Supreme Court decision No. 78 PK/TUN/2011) can not be executed. This method of research uses normative legal research methods. The approach is used are the conceptual approach, the legislation approach, and the case approach. The result of this research is the first basic consideration of legal ownership of land rights is the regulation of the Minister of Agrarian of the head of National Land Agency number 9 of 1999 about the procedure for granting and annulment of land rights and management rights, government regulation Number 10 of 1961 concerning land registration, government Regulation Number 24 of 1997 about land registration, regulation of the Minister of the Interior number 5 of 1974 about the conditions on the provision and giving of land for corporate purposes, and regulation of the Minister of the Interior number 15 of 1975 about the provisions on the Ordinance of Land acquisition. Secondly, land rights disputes that has a permanent legal force or can not be executed (Incrah) due to rules relating to the application of land rights certificate above Management Rights, has not been set or has been revoked and not valid since the issuance of regulation of the Minister of Agrarian state/head of national Land Agency No. 9 of 1999 on procedures for granting and canceling rights to land and management rights.
\end{abstract}

DOI: $10.7176 / \mathrm{JLPG} / 98-04$

Publication date:June 30th 2020

\section{INTRODUCTION}

Land is an important natural resource for survival for mankind, human relationships with land is not just a place of life, but more than that land provides resources for the survival of mankind. For the nation of Indonesia, land is the gift of Almighty God and is a national wealth, which means of organizing all the activities of the people's life and also has an important role for survival for mankind, as well as the importance of the State, especially in supporting the development activities of the field, always need land as a place for the implementation of the development activities. Therefore the land must be managed carefully to be beneficial to the life of mankind in the present and future.

Indonesia has the largest archipelago in the world that has many islands, the name of the alternative that is commonly used is "Nusantara", not to be separated from that Indonesia also has a lot of diversity from different religions, tribes, and cultures, such as one of the provinces in West Nusa Tenggara that has a variety of cultures, religions, and different tribes but West Nusa Tenggara also has a lot of places or areas that are a tourist destination and one of ten destinations in Indonesia, one of the tourist destinations in Lombok Island that we know is Mandalika Beach South Lombok which is known as the Special Economic area.

Pursuant to article 1 of law number 39 of 2009 concerning the Special Economic area stated that:

The Special Economic Area (hereinafter referred to as KEK) is a region with a certain boundary within the jurisdiction of the unitary State of the Republic of Indonesia which is set to hold economic function and obtain certain facilities.

According to article 1 of law number 39 of 2009 about the Special Economic area, then the special Economic Area located in central Lombok is managed by PT. ITDC (Indonesia Tourism Development Corporation). PT. ITDC is one of the State-Owned Enterprises (hereinafter referred to as BUMN) that manages the area of South central Lombok which is known as Kuta Beach, Mandalika becomes a tourist area equipped with the infrastructure and facilities of hotels, villas and others.

In line with the determination of the Special Economic Area $(K E K)$ Mandalika Central Lombok Regency as a tourist area, then PT. ITDC which was originally named PT. LTDC conducts land acquisition/land belonging to citizens. Land acquisition/land referred to some problems related to the existence of several rights to the land of citizens, such as Proprietary Certificate (hereinafter referred to as $S H M$ ), the letter of mastery of land rights (Sporadik), Letter of Control and others. The problem of land rights disputes is a very sensitive matter, perhaps due to its nature which is a basic necessity, but the number of resources are limited or is not balanced between 
supply and demand, which has been compounded by the action of the speculator and participatory/landlord who controls various fields of land on behalf of the "investment" at the same time some members of the community still farming or residential on the basis of tenancy.

The causes of disputes in the area of the region, one member of the community submitted an application for property rights but the application was rejected by the National Land Agency (hereinafter referred to as BPN).

The reasons in accordance with the ruling of the Supreme Court No. 78 PK/TUN/2011 are:

1. That the land which is proposed is included in a certificate of Building Rights (hereinafter referred to as $H G B)$ No. 4 Sengkol Village recorded on behalf of PT. LTDC

2. Concerning with number 1 (one) then the application cannot be considered and we return the application file and strikethrough from the list of the right application register.

The reasons for the rejection of the Certificate of Rights in the applicant made a legal effort through the Mataram State Administrative Court to the Supreme Court (cassation/reconsideration).

The dispute, the parties or some Parties select to settle litigation and non litigation. The parties who dispute in the Mandalika Special Economic area have been resolved through a legal or litigation line through a first-rate court/State Administrative Court up to the final level/Supreme Court (in this case PT. ITDC as the defendant or the respondent and landlord as the plaintiff or applicant). According to the decision of the Supreme Court Decree No. 78 PK/TUN/2011, with Amar verdict: denied the Reconsideration Request from the applicant reconsideration PT. LTDC.

The process of ownership of land rights for the plaintiff or the applicant who is granted the petition by the judges (ruling on the Incrah; has a permanent legal force), administratively by the government/National Land Agency can not issue an application for assigning rights to a plot of land (Land certificate).

The application of property rights in the land of the state stipulated in article 9 paragraph (1) and paragraph (2) of the regulation of the Minister of Agrarian/Head of land agency number 9 of 1999 on procedures for granting and annulment of national land and management rights.

(1) The application of proprietary rights to the State land is submitted in writing.

(2) The application of title as intended in paragraph (1) shall contain:

1. Information about the applicant:

a. If the individual: name, age, nationality, residence and occupation as well as information about the wife/husband and his/her child who is still his/her departure;

b. If the legal entity: its name, place of establishment, deed or regulation, the date and number of the endorsement letter by the authorized official of the appointment as a legal entity that can have property under the provisions of the prevailing laws and regulations.

2. Description of the soil including juridical data and physical data:

a. The basis of the mastery or the right base can be a certificate, Girik, letter of Kavling, letters of discharge proofand settlement of land and house and/or land that has been purchased from the government, the ruling of the court, the deed of Land Deed Official, the Waiver of Rights, and other evidence of land acquisition;

b. Location, boundaries and extent (if there is a measuring letter or picture of the situation of the date and number);

c. Soil type (agriculture/non-agricultural)

d. Land use plan;

e. The Status of the soil (land rights or state land);

3. Other:

Information on the number of fields, area and status of the land owned by the applicant, including the field of land that is requested; Other information deemed necessary.

Pursuant to article 9 of regulation of the Minister of Agrarian/Head of national Land Agency No. 9 of 1999 on procedures for granting and canceling rights of land and this management rights governing the issuance of Proprietary Certificates shall not be applied by the government/National Land Agency by reason Proprietary Certificates can not be issued on top of the certificate of Management rights while the issuance of the proprietary certificate on top of the certificate of Management rights was previously stipulated in the Ministerial regulation of the Interior No. 1 of 1977 on procedures of application and settlement of rights to the land parts management rights and registration, but the regulation has been revoked with the issuance of regulation of the Minister of Agrarian state/head of national Land Agency No. 9 of 1999 on procedures for granting and annulment of land rights and management rights, which regulation of legislation governing further rights on HPL does not exist/no governing, meaning in such arrangement there is a void of law.

\section{RESEARCH METHOD}

The type of research is used in this writing is normative legal research. The approach is used in this research are the conceptual approach, the of approach, and the Case approach. The legal material used in this legal research is 
the primary law material, which is the legal materials that have binding strength, the form of national law resources include other laws and regulations. Secondary legal material, which is the legal materials that provide an explanation about the primary legal material, the form of research and writing in the field of law obtained from legal literature include: books, journals, magazines, newspapers, theses and dissertations. Tertiary material, i.e. materials that provide instruction and explanation and to help understand the terms used in the research of primary legal materials and secondary legal materials so that their nature as supporting materials include: Legal dictionary, Dictionary of Bahasa Indonesia and others.

The techniques which are used in collecting the legal materials are in normative legal research, techniques for reviewing and analyzing the primary legal materials, secondary legal materials and tertiary legal substances i.e. using Documenter studies. A documentary study is a study that examines documents, with respect to the legislation which in this case covers the law No. 5 of 1960 concerning Main Agrarian Regulations (hereinafter referred to as UUPA), regulation of the Minister of Agrarian/Head of national Land Agency No. 9 of 1999 on procedures for granting and cancelling the rights to state land and other regulatory and legislation management rights, as well as existing documents.

\section{DISCUSSION}

\section{Consideration of legal ownership of land rights above HPL certificate (management rights)}

Basic legal consideration of ownership of land rights above HPL certificate (Management rights) in special Economic Area Mandalika Central Lombok District

1. Understanding of Legal considerations

Legal considerations is closely related to the judge's consideration of the legal reasoning of the case. Reasoning is a logical and analytical activity according to a particular pattern, unlike intuition although it is a thought activity but not based on a particular pattern. ${ }^{1}$ The simple meaning of Legal Reasoning is reasoning about the law of "reason" searching for the law or the basic search of how a judge decides a lawsuit/legal case, an attorney argues for the law and how a legal expert has the law. ${ }^{2}$ The reasoning of the law is done in the zones or domains of the scientific territory, both in terms of doctrinal and non-doctrinal, using a variety of approaches to its scientific support. ${ }^{3}$

2. Kinds of methods of discovery Law

If the rule of law is not clear, it will be used method of interpretation, and if the legislation is incomplete or does not exist it will be used method of argument, and if the regulation does not exist then will be used method of legal construction. ${ }^{4}$

The practice of the judiciary recognizes several methods of interpretation: subsumptive interpretation; Grammatical interpretation; Systematic/logical interpretation; Historical interpretation; teleological/sociological interpretation; Comparative interpretation; Anticipatory/futuristic interpretation; Restrictive interpretation; extensive interpretation; Authentic or formal interpretation; Interdisciplinary multidisciplinary interpretation; Interpretation of the Treaty (Sudikno Mertokusumo, 1996, H. 14-20).

3. Management rights settings in Indonesia

Speaking of management rights in Indonesia, it will not be separated from legal bases that can be used in analyzing the rights of such management, including but not limited to: ${ }^{5}$

a. Article 2 paragraph (4) UUPA (Delegation of authority);

b. General explanation of UUPA numeral II number 2;

c. Government regulation number 8 of 1953 concerning the mastery of State lands;

d. Articles 1, 2, 5 and 9 of the regulation of the Minister of Agrarian number 9 of 1965 on the implementation of conversion rights to the State land and subsequent wisdom;

e. Article 1 Letter B of Ministry of Agrarian Regulation number 1 of 1966;

f. Article 5 and 6 of Ministry of Home Affairs number 5 of 1974;

g. Article 2 Ministry of Home Affairs number 1 of 1977;

h. Article 2, 1 paragraph 2 of government Regulation number 36 of 1997;

i. Regulation of the Ministry of Home Affairs of 1972 amended by regulation of the Minister of Agrarian Affairs/Head of National Land Agency number 3 of 1999, amended by regulation of the head of National Land Agency of the Republic of Indonesia number 2 of 2013;

j. Article 29 regulation of the Ministry of Home Affairs number 5 of 1973 and amended by regulation of the Minister of Agrarian state/head of National Land Agency number 9 of 1999, in article 1 and article 67;

\footnotetext{
${ }^{1}$ Syarif Mappiasse, Logika Hukum Pertimbangan Putusan Hakim, Prenadamedia Group, Jakarta, 2015, p. 141

${ }^{2}$ http://asikinzainal.blogspot.com/2012/08/penalaran-hukum-legal-reasoning.html diakses pada tanggal 23 Januari 2019

${ }^{3}$ Nurul qamal dan salle, Logika Dan Penalaran dalam Ilmu Hukum, CV. Social Politic Genius, Makassar, 2018. p. 2

4 Ibid p. 48

${ }^{5}$ Sri Hajati , dkk, Buku Ajar Politik Hukum Pertanahan, Airlangga University Press, Surabaya, 2018, hlm. 176
} 
k. Article 9.1 paragraph (4) of government Regulation number 24 year 1997 on land registration;

1. Article 7 paragraph (1) of Law number 16 year 1985

4. Legal consideration of ownership of land rights above HPL certificate (management rights)

The legal considerations in the writing of this scientific works is legal considerations relating to the judgment of the judge in conducting legal reasoning or logical and analytical activity according to certain patterns in deciding a lawsuit/law case.

Basic consideration of judges in establishing ownership of land rights of land management rights (HPL) in the Special economic area which is poured in the decision of the Supreme Court of the Republic of Indonesia which has become the law to be respected, adhered to both parties litigated.

The decision of the Supreme Court of the Republic of Indonesia No. 78 PK/TUN/2011, examines the State Administration issues in the reconsideration $(P K)$ has decided with juridical legal considerations and facts. Legal considerations and facts in question:

1) Application for certificate;

That each applicant's proprietary certificate on a plot of land $(S H M)$ can be issued if it has been through the following stages:

a. Registration and payment of administrative fees in accordance with the provisions stipulated by the National Land Agency (BPN);

b. Soil measurements;

c. Team A inspection.

These three stages have been done by the applicant according to the provisions stipulated in Article 13 of the regulation of the Minister of Agrarian state/head of national Land No. 9 of 1999 concerning Procedures for Granting and Canceling Rights to Land and Management Rights.

Land registration rights is also in accordance with the provisions of Article 18 Government Regulation No. 10 of 1961, and has Sporadik pursuant to article 1 Figure 11 Jo Article 13 paragraf 4 Government Regulation number 24 of 1997 and the land has been registered systematically in accordance with the provisions of article 1 to Article 12 Government Regulation No. 10 of 1961 or pursuant to article 1 numeral 10 Jo Article 13 Paragraph 2 Government Regulation number 24 of 1997 and has not been proposed in the National Agrarian Project to obtain a certificate as the provisions of the Decree of the Ministry of Home Affairs of 1981.

2) Deeds against the law and against the rights

Defendant in the application for Building Rights Application certificate No. 4 of Sengkol Village on 20 January 1994, without the knowledge and permission of the owner (plaintiff) and has no fundamental reason, this action is an act against the law and against the right and violate the provisions as stipulated in regulation of the Ministry of Home Affairs number 5 of 1973 and regulation of the Ministry of Home Affairs number 5 of 1974 and chapter IV concerning : Ordinances of land provision and land acquisition required, article 11 paragraph 3 which reads: "The implementation of the purchase or the liberation of rights and Tanah-tanahnya Mastery are conducted on the basis of deliberation with the parties that own $i t^{\prime \prime}$ and the regulation of the Minister of Home Affairs No. 15 of 1975 concerning the provisions on the Ordinance of Land Acquisition chapter III on land acquisition for private : "The liberation of land for private purposes shall be done directly between the parties concerned with the compensation by referring to the principle of deliberation", that is not done at all by the party of PT. LTDC which is one of the requirements and the basis in applying for building use Rights Certificate No. 4 Sengkol Village which becomes a necessity to be observed, examined and researched by the defendant before processing and published the decision letter of the State Administration (Certificate of Building Rights No. 4 of Sengkol Village on 20 January 1994), it was not conducted by the defendant and has violated and contrary to prevailing legislation and violates The Good General Gvernance Principles.

3) Dispute object.

Disputed objects are still mastered and worked out by the Plaintiff and the heirs, and are never transferred to other parties including to PT. LTDC, both in the form of buying and selling other legal acts, legally the actions and deeds carried out by the defendant $(B P N)$ that issued the decision letter of the State Administration on the land of the plaintiff's rights are acts against the law and against the rights and violate the provisions of the law and the detriment of the plaintiff.

The considerations of the judges outlined above are legal considerations set forth in the Supreme Court ruling No. 293K/TUN/2009 on the terms of the State Administration and have been declared Incrah (has a permanent legal force), and the verdict of the Supreme Court Judge of the Republic of Indonesia No. 78/PK/TUN/2011 at the examination of the State administration in the reconsideration, decided that the State Administrative Decree issued a Building Rights Certificate No. 4 Sengkol Village recorded on behalf

PT. LTDC is canceled. 
From the consideration of the judges in making the ruling on the state's administrative matters above, the basic legal consideration of ownership of land rights above management rights:

a. Article 11 paragraph (3) Regulation of the Minister of Home Affairs number 5 of 1974 chapter IV on the Ordinances of land provision and land acquisition required;

b. Article 11 paragraph (2) of chapter III, regulation of the Minister of Home Affairs number 15 of 1975 concerning the provisions on the Ordinance of Land acquisition;

c. Article 18 Government Regulation Number 10 of 1961 concerning land registration;

d. Article 1 numeral 11 Jo Article 13 paragraph (4) Government Regulation number 24 of 1997 concerning land registration;

e. Article 1 through article 12 of the Government regulation of 1961, article 1 numeral 10 Jo Article 13 paragraph (2) Government Regulation number 24 of 1997.

Building Rights Certificate Revocation verdict number 4 Sengkol village subdistrict of Pujut central Lombok by the Supreme Court of the Republic of Indonesia is a legal basis for ownership of land rights above management Rights (HPL), because the proprietary certificate on the piece of land is not able to be issued on top of the Management rights certificate (HPL).

Land rights disputes that have had a permanent legal force or an incline in the Mandalika Central Lombok Special Economic Area (Supreme Court ruling No. 78 PK/TUN/2011) cannot be executed

Land Rights Disputes

In conducting life activities, the occurrence of contact between human beings or legal entities, both in the form of interpersonal relationships and business transactions can cause reaction. The contact can cause a positive reaction, which is a reaction that does not cause harm to the parties or negative reactions, which is the reaction that causes harm to either party causing disputes. ${ }^{1}$

The definition of dispute according to the Great Indonesia Dictionary is something that causes disagreements, quarrels, disputations, disputes that cannot be solved. ${ }^{2}$ Disputes can be caused by various factors, such as differences of interest or dispute between the parties with the other. It can also be caused by the rigid rules that are considered as barriers and barriers to achieve the objectives of each party. ${ }^{3}$

The rights of land as a legal relationship is defined as the right to the Earth's surface authorizing the holder to use the land in question, and the body of the earth and the water and the air on it, simply necessary for the sake of directly relating to the use of the land.

Pursuant to article 16 paragraph (1) of Law No. 5 of 1960 concerning basic agrarian regulations that reads:

(1) The rights to the land as referred to in article 4 paragraph (1) are:

a. Proprietary rights

b. Business rights

c. Building rights

d. Right of Use

e. Lease rights

f. Land opening rights

g. Right to pick up forest results

$\mathrm{h}$. Other rights not included in the above rights shall be stipulated by the law and its provisional rights as specified in Article 53.

Legal Remedies Against Verdict

In order to obtain justice in question, the law has organized some legal remedies to gain justice in the judicial process, among others

1. Appeal ${ }^{4}$

For those who are defeated by Verstek Verdict and Resistance (verzet) and in the ordinary decision of the District Court and are not satisfied with the ruling, because feeling his/her rights are attacked by the ruling or assuming the verdict is less true or less fair, then he can apply for an examination in the appeal of a high court, in hopes of being dropped by a different verdict by the original verdict or at least the verdict of the state court to be raw again and the execution of the decision can be temporarily suspended until the ruling Gain definite strength (incraht van Gewijsde).

Furthermore, that can apply for appeals is in question. Given that the appeal is a legal remedy for the improvement of the decision which is more profitable, and also that the appeal is not appropriate for the party won, then the appeal is only reserved for the party that is defeated or feels harmed.

\footnotetext{
1 Jimmy Joes Sembiring, Cara Menyelesaikan Sengketa Di Luar Pengadilan, Visimedia, Jakarta, 2011, p. 1

${ }^{2}$ Departemen Pendidikan Dan Kebudayaan, op.cit p. 914.

3 Jimmy Joes Sembiring, Op.Cit, p. 1-2

${ }^{4}$ Bambang Sugeng A.S, Op.Cit, p. $92-95$
} 
2. Casation ${ }^{1}$

All judgments given in the final level by other courts of the Supreme Court, as well as the ruling on the Court of Appeal may be appealed to the Supreme Court by the interested parties (article 10 paragraph (3) UU No. 20 of 1947, article 43 LAW No. 14 of 1985).

The underlying provisions of the cassation are governed by the law No. 14 of 1985 concerning the Supreme Court, as amended in Law No. 5 of 2004 on Amendment to law No. 14 of 1985 on the Supreme Court.Casation may be submitted by the parties concerned, and these interested parties may represent to a person who is specifically authorized (article 44 LAW No. 14 of 1985).

In the period of 14 days after the application referred in the applicant's register of Casasi is obliged to convey the memory of the casation (article 47 UU No. 14 of1985).

3. Reconsideration ${ }^{2}$

The verdict that is dropped in the last level and the ruling that was dropped outside the presence of the defendant (verstek) and which is no longer open is likely to propose resistance may be reviewed at the request of a person who had been a party in the matter that had been disconnected and requested a review again.

The review is governed under LAW No. 14 of 1985, from chapters 66 to section 77. The request for review can be submitted either in writing or orally (article 71 UU No. 14 of 1985) by the parties themselves (Article 68 paragraph (1) UU No. 14 of 1985) to the Supreme Court through the Chairman of the District Court who severed the matter in the first level (article 70 UU No. 14 of 1985).

Further, within 14 days after the head of the District court who severed the first level of accepting the request for review, the clerk sent a copy of the petition to the opposing party.

The request for review does not suspend or terminate the court ruling and may be revoked as long as it has not been terminated and can only be submitted once (article 66 UU No. 14 of 1985).

Land Rights That Have A Fixed Or Incrah Legal Force

1. Chronological application of land rights

The applicant, the owner or the plaintiff performs several stages of preparation of the administrative requirements to complement the certificate of application of proprietary rights of land:

a. Preliminary preparation (administrative completeness)

At the initial preparation of the owner, the applicant or plaintiff prepares the completeness of the papers as the requirements for the application of the rights certificate to the National Land Agency (BPN), as follows:

1) The Declaration of the lands to which the applicant is on stamp;

2) A certificate of mastering/owning and controlling a plot of land signed by the village chief;

3) A waiver on the possession of a plot area of $22140 \mathrm{M}^{2}$, on the stamp;

4) The Certificate of land ownership is signed by the landlord on the stamp, which is signed by the Dusun, and witnesses, knowing the chief of the village;

5) A declaration of ownership of a plot of land of $22140 \mathrm{M}^{2}$, in accordance with the measurement results by the measuring officers of the National Land Agency with the boundaries of the plot of land in accordance with the limits of the letter, the statement letter on stamp;

6) A letter of physical mastery of a plot of land (Sporadik) signed by the landlord, the village chief and the witness, knowing the chief of the villages.

The requirements of such application are in accordance with the form of the National Land Agency

b. Application for certificate to National Land Agency

Applying for a certificate (according to form 402 application of Proprietary rights, Building rights, Right of Use, Managing Rights) is delivered to the National Land Agency according to the aforementioned requirements (point a).

The certificate application letter is rejected by the National Land Agency with the letter of refusal of property rights in the name of plaintiff number 600/741/2007, dated August 27. By reason of the land that was asked the certificate has been certified to building rights No. 4 Sengkol Village on behalf of PT. LTDC) on the Managing Rights with the decree of the Head of Regional office of West Nusa Tenggara provincial land number SK. 550.2/70/1/116/62/1994

c. Remedies through Mataram State Administrative Court

1) The basis of the plaintiff's lawsuit to the State Administrative Court is the decree of the State Administrative Court issued by the National Land Agency (BPN) in the issuance of the building rights certificate No. 4 Sengkol Village on behalf of PT. LTDC dated 19 January 1994, above the management rights number 1/village Sengkol on behalf of the provincial government of West Nusa Tenggara Province on 20 July 1992.

\footnotetext{
${ }^{1}$ Ibid, p. $95-97$

${ }^{2}$ Ibid, p. $97-98$
} 
In the decision of the State Administrative Court Mataram number 17/G/2008/PTUN. Mtr. Examining the lawsuit decided that the issuance of the building use Rights Certificate No. 4 Village Sengkol on behalf of PT. LTDC by the National Land Agency is an act against the law and against the right and the breach of Article 11 paragraph 3 of the Minister of Home Affairs number 5 of 1974 and regulation of the Minister of Home Affairs number 5 year 1973 and regulation of the Minister of Home Affairs No. 15 of 1975 concerning the provisions on the Ordinance of Land Liberation Chapter III concerning land acquisition for private

2) Defendant petitioned the appeal against the plaintiff (the respondent).The defendant's appeal (applicant), the State Administrative High Court rejected an appeal from the applicant of appeal: PT. LTDC and the applicant II: Head of the Land Office of Central Lombok Regency.

3) The defendant undertook an application for the legal appeal of the plaintiff (the respondent).

Defendant (applicant), the Supreme Court of the Republic of Indonesia rejects the application of cassation from the applicant I Cassation I: PT. LTDC and the applicant Cassation II: Head of the Land office of central Lombok Regency.

4) Defendant is applying for a legal remedy review of the plaintiff (respondent).Attempted reconsideration of the defendant (applicant), the Supreme Court of the Republic of Indonesia rejected the application for review of the applicant reconsideration: PT. LTDC.

2. Execution of Supreme Court decision of the Republic of Indonesia

Execution of the decision of the State Administration is not equal or different from the execution of civil and criminal lawsuit, civil and criminal conduct execution can be done by the District Court by force to seek assistance from the police force while the execution of the ruling State Administration relies heavily on the State Administrative Court and the legal awareness of the relevant officials.

From the descriptions above, then to follow up the decision of the Supreme Court of the Republic of Indonesia, the plaintiff or applicant Certificate of property rights to submit an application to the National Land Agency by attaching the verdict of the Supreme Court of the Republic of Indonesia, but the application of proprietary certificates still can not be processed.

Pursuant to article 3 paragraph (2) and paragraph (3) of Law No. 5 of1986 concerning the judicial administration of State, article 3 paragraph (2) reads:

"If an agency or State Administration office does not issue the requested decision, while the period as specified in the legislation mentioned has passed, then the agency or the administrative office of the State is deemed to have refused to issue the stated decision."

Article 3 paragraph (3) reads:

"In the case that the legislation in question does not determine the period as referred to in paragraph (2), then after a period of four months from the receipt of the request, the Agency or the administrative office of the State concerned is deemed to have issued a decision of rejection."

The rejection of the National Land Agency on application of the above rights certificate is a form of rejection of execution of the Supreme Court decision of the Republic of Indonesia, the rejection of the National Land Agency based on regulations governing the issuance of proprietary rights certificate (regulation of the Minister of the Interior number 1 of 1977 governing on the procedure for application and settlement of rights to the land Rights Management and its registration) repealed and no longer valid since published regulation of the Minister of Agrarian state/head of national Land Agency No. 9 of 1999 on procedures for granting and cancelling rights to land and management rights.

\section{CONCLUSION}

Basic legal considerations made by the judge in the determination of the dispute on land rights in accordance with the fact of the prevailing legislation (Article 13 Regulation of the Minister of Agrarian Head of the National Land Agency number 9 of 1999 about the procedure for granting and cancelling rights to land and management rights, article 1 to 12, and Article 18 government Regulation No. 10 of 1961 on land registration article 1 Figure 10 Jo Article 13 paragraph (2) government Regulation Number 24 of 1997 concerning land registration, and article 1 numeral 11 Jo Article 13 paragraph (4) government Regulation number 24 of 1997 on land Registration, article 11 paragraph (3) Regulation of the Minister of the Interior number 5 year 1974 concerning provisions on provision and provision of land for corporate purposes, and article 11 paragraph (2) of regulation of the Ministry of Interior No. 15 of 1975 concerning the provisions on the Ordinance of Land Acquisition).

The dispute on land rights disputes that have had the permanent legal force of the Supreme Court of the Republic of Indonesia No. 78/PK/TUN/2011 Can not be executed in the form of issuance of proprietary certificates that are asked by the plaintiff, because in the regulation of the Minister of Home Affairs No. 1 of 1977 which governs the procedure of application and settlement of rights to the land parts management and registration, repealed and not valid since published regulation of the Minister of Agrarian state/head of national Land Agency No. 9 of 1999 on procedures for granting and annulment of land rights and management rights. 


\section{REFFERENCES}

Syarif Mappiasse. 2015. Logika Hukum Pertimbangan Putusan Hakim, Prenadamedia Group, Jakarta Nurul qamal dan salle. 2018. Logika Dan Penalaran dalam Ilmu Hukum, CV. Social Politic Genius, Makassar Sri Hajati, dkk. 2018. Buku Ajar Politik Hukum Pertanahan, Airlangga University Press, Surabaya. Jimmy Joes Sembiring. 2011. Cara Menyelesaikan Sengketa Di Luar Pengadilan, Visimedia, Jakarta.

Bambang Sugeng A.S. 2013. Pengantar Hukum Acara Perdata Dan Contoh Dokumen Litigasi, Prenadamedia Group, Jakarta.

Departemen Pendidikan Dan Kebudayaan. 1989. kamus besar bahasa Indonesia, Balai Pustaka, Jakarta.

Indonesia, Law No. 5 of 1960 on Basic Agrarian Regulations; (Government Gazette of 1960 number 104, addition to Government Gazette 2043)

Indonesia, Law No. 39 yof 2009 of the Special Economic Area (Supplementary State Gazette of the Republic of Indonesia number 5066)

Indonesia, regulation of the Minister of Agrarian state/head of National Land Agency number 1 of 1999 on procedures of handling disputes of agrarian State Minister/Head of national Land Agency

Indonesia, regulation of the Minister of Agrarian state/head of national Land Agency No. 9 of 1999 on procedures for granting and annulment of land rights and management rights 